\title{
Canopy gaps and tree regeneration patterns in multi-species unmanaged natural forest Sitno (preliminary results)
}

\section{Danková, M. Saniga}

Technical University in Zvolen, Faculty of Forestry, Department of Silviculture, T.G. Masaryka 24, SK-960 53 Zvolen, Slovak Republic,E-mail:lucia.dankova@tuzvo.sk

Abstract: Danková, L., Saniga, M. 2013: Canopy gaps and tree regeneration patterns in multi-species unmanaged natural forest Sitno. - Beskydy, 6 (1): 17-26

The study of canopy gaps structure and tree regeneration patterns was conducted in mixed old-growth forest Sitno. We asked the following questions: What is the spatial scale of disturbance events? How does gap size affect the density of tree seedlings and saplings? Are there any differences in species composition of seedlings and saplings between the closed canopy and expanded gap? The research was conducted on a 2.5ha $(250 \times 100 \mathrm{~m})$ research plot. In total, 25 canopy openings were recorded. Canopy gaps and expanded gaps covered $22.8 \%$ and $59.5 \%$ of the research area. The most frequent were canopy gaps with the size up to $300 \mathrm{~m}^{2}$ (64\%). Regarding the number of gapmakers, we recorded a quite large variability with the highest frequency of the gaps with 1 and 4 gapmakers. Regeneration structure (density and frequency) was sampled in $3.14 \mathrm{~m}^{2}$ circular plot $(\mathrm{n}=216)$ established on the grid intersections $(10 \times 10 \mathrm{~m})$. A total of 8 tree species were identified in natural regeneration. The difference between overall density of natural regeneration under closed canopy and in expanded gaps was observed. The density of all tree species seedlings (except of Carpinus betulus) was higher under closed canopy than in expanded gaps. The most frequent were seedlings of Acer pseudoplatanus and Acerplatanoides which occurred on $80 \%$ and $73 \%$ of the plots under closed canopy, and $75 \%$ and $68 \%$ of the plots in expanded gaps. Seedlings of Quercus petraea were not recorded. Density of saplings was higher in expanded gaps than under canopy (except of saplings of Acer platanoides and Tilia cordata). The density of saplings of Acer pseudoplatanus and Acer platanoides increased with increasing size of expanded gap, while Fraxinus excelsior saplings density decreased. There was no significant relationship between density of other species seedlings and saplings and expanded gap size.

Key words: expanded gaps, density of natural regeneration, multi-species unmanaged natural forest

\section{Introduction}

Natural forests provide appropriate object for study natural processes and structures. Return toclose-to-nature silviculture (Schütz 1999), increase of ecological diversity and stability, decrease of area of artificial simple forest stands based on the age class management is the reaction to growing demands (interest) of timber production as well as demands arising from society for recreational, ecological, and protective functions of forest ecosystems (Heiri et al. 2009, Liira et al. 2011).
Natural regeneration plays the important role for establishment and development of stable "native" forest stands. Studies of gap dynamics can contribute to our understanding of the role of small-scale disturbance in forest ecosystems and help foresters to predict tree response to partial cutting (Bengtsson et al. 2000, Coates 2000). Natural disturbances and life-history characteristics are key factors in coexistence of tree species (White 1979, Loehle 2000). Many forests maintain high species diversity as a result of canopy gap regeneration processes 
(Grubb 1977, Ricklefs 1977, Denslow 1980, Orians 1982). The observed patterns of recruitment are a result of a broad suite of factors including mast seeding, seed dispersal opportunities (abundance, location and arrangement of parent trees), diversity and distribution of seedbeds, microclimate, potential for vegetative reproduction and intensity of seed predation and browsing (e.g. Farmer 1997 in Coates 2002). Moreover, the death of a canopy tree dramatically changes the light level in the forest understorey and enhances tree regeneration (Denslow 1987). In closed forest ecosystems, light availability is a major constraint on tree growth and survival, and an important axis for differentiation of the ecophysiology, architecture, and demography of tree species (Gravel et al. 2010). Differences in species shade-tolerance levels may determine the ability of immature individuals to grow and survive in gaps of different sizes (Schnitzer and Carson 2001; Imai et al. 2006). At one extreme are shade-tolerant species with juveniles that have elevated survival rates under low light conditions but only moderate response to canopy openings. At the other extreme are shade-intolerant species with juveniles that experience high mortality under low light but have a strong growth response to canopy openings (Canham 1989 in Gravel at al. 2010). The requirements of pioneer species for high light levels for seed germination and seedling growth are well known (Brokaw 1985, Beaudet and Messier 1998, Lei and Lechowicz 1998, Einhorn et al. 2004). Where light intensity is high, as in the centers of large gaps, both pioneer and shade-tolerant species are able to establish and grow (Denslow et al. 1990). But some studies showed that gap size did not have to influence on gap-filler composition (Bobiec 2007).

It is less studied how gaps influence the coexistence of species with different shade tolerance. Beech and mixed-beech forests of temperate Europe, in which Fagus sylvatica is a dominant or co-dominant tree are widespread and represent the potential natural vegetation of many areas of the lowlands of NW and NC Europe and the mountains of C, S, and E Europe (Ellenberg 1996, Jahn 1991). Therefore, most studies of oldgrowth stands and natural reserves in Europe are conducted in beech dominated forests (Standovár and Kenderes 2003, Oheimb et al. 2005). The existence of multi-species deciduous European forests is scarce (Bobiec et al. 2000, 2007; Emborg et al. 2000). Unmanaged natural forest in Sitno which consists of 8 tree species, such as European beech (Fagus sylvatica L.), maples (Acer pseudoplatanus L., Acer platanoides L.), ash (Fraxinus excelsior L.), oak (Quercus petraea (Matt.) Liebl.)), lime ( Mill.), Scotch elm (Ulmus scabra Mill.) and fir (Abies alba Mill.) could be considered one of the best existing examples of relatively undisturbed remnant of mixed natural forest in Slovakia and central Europe.

This study was designed to address the following questions. (1) What is the spatial scale of disturbance events? (2) How does gap size affect the density of tree seedlings and saplings? (3) Are there any differences in species composition of seedlings and saplings between the closed canopy and expanded gaps?

\section{Methods}

\section{Study area}

The study site $\left(48^{\circ} 23^{\prime} 55^{\prime \prime} \mathrm{N}\right.$; 18 $\left.18^{\circ} 52^{\prime} 54^{\prime \prime} \mathrm{E}\right)$ is located in National Nature Reserve (NNR) Sitno in the Štiavnicke vrchy Mts., central Slovakia, Western Carpathians. The reserve of 45.49 ha established in 1951, was extended in 1983 to 93.68 ha. It is located between 770 and $940 \mathrm{~m}$ a.s.l. with S and SE exposition. Average annual precipitation is $907 \mathrm{~mm}$. Mean annual temperature is $14{ }^{\circ} \mathrm{C}$, ranging from $-4.6^{\circ} \mathrm{C}$ in January to $17.4{ }^{\circ} \mathrm{C}$ in July. Bedrock consists of volcanic rocks, andesite and pyroxene. The predominant soil type is eutric cambisol, well aerated, with high share of rocks, with rapid draining.

Vegetation in NNR Sitno can be divided into four forest types. The mixed oak-beech forest dominated by Querceto-Fagetum association is the most wide-spread.

Old-growth stands are formed by more than eight tree species: Acer pseudoplatanus, Acer platanoides, Fraxinus excelsior, Fagus sylvatica, Tilia cordata, Ulmus scabra, Carpinus betulus and Quercus petraea (Kolektív 2004).

\section{Field measurments and data analysis}

The research was conducted on a 2.5 ha $(250 \times 100 \mathrm{~m})$ research plot (RP) established in the reserve in summer 2011. The location of the plot was selected in the central core zone of the reserve. We used two gap definitions (in accordance with Runkle 1982): canopy gap and expanded gap. He defined the canopy gap as the land surface area directly under the canopy opening, and the expanded gap as the canopy gap plus the adjacent area extending to the bases of canopy trees surrounding the canopy gap. We defined gaps as a openings in the forest canopy $>5 \mathrm{~m}^{2}$ caused by the mortality of a canopy tree (one tree and more) $>25 \mathrm{~cm}$ diameter at breast 
height (DBH), so we considered gaps when the remains of a gapmaker were present. The data (position and crown projection of trees surrounding the canopy gap) were collected and digitized, and the gap sizes were calculated using the Field-Map ${ }^{\infty}$ software package.

Natural regeneration was studied in $3.14 \mathrm{~m}^{2}$ circular plots (i.e. $1 \mathrm{~m}$ in radius, $\mathrm{n}=216$ ) established on the grid intersections. The grid $(10 \times 10 \mathrm{~m})$ was established on the whole research plot. The number of individuals of each species and height were counted and measured. Then we categorized them within two height classes, which include seedlings ( $\leq 50 \mathrm{~cm}$ of height) and saplings ( $>50 \mathrm{~cm}$; $\mathrm{DBH} \leq 4 \mathrm{~cm}$ ).

Gaps' characteristics (canopy gap and expanded gap) were described in terms of relative numbers of gaps of different size classes, proportion of gaps within the whole study area and numbers of gapmakers per gap.

The relative importance values of natural regeneration (density and frequency) were evaluated under canopy and expanded gap. The relative density of natural regeneration means the number of individuals of one tree species as a percentage of the total number of individuals (calculated per gap) was examined with Spearman's correlations. Correlations were performed separately for the dominant species in the regeneration layer and for total regeneration density at different height classes.

\section{Results}

\section{Stand characteristics}

The mean stem density of canopy trees 603 stems.ha ${ }^{-1}$ and basal area of $39.8 \mathrm{~m}^{2} \cdot \mathrm{ha}^{-1}$ was recorded (Tab. 1). Acer pseudoplatanus and Fagus sylvatica represented the dominant tree species. The abundance of Fraxinus excelsior was high (16.4\%). In spite of high number of A.pseudoplatanus (34.8\%), its proportion from the basal area was only $19.1 \%$, what reflected predominanace of this tree species in lower diameter classes. On the other hand, F. sylvatica was represented by more than $38 \%$ of the total basal area. The abundance of other tree species did not reach either $10 \%$, as well as their proportion from basal area (Tab. 1).

Tab. 1: Basic characteristics of the living trees $(\mathrm{DBH} \geq 4 \mathrm{~cm})$ on $R P$.

\begin{tabular}{lcccc}
\hline \multicolumn{1}{c}{ Tree species } & \multicolumn{2}{c}{ Stem density } & \multicolumn{2}{c}{ Basal area } \\
\cline { 2 - 5 } & $\mathbf{N . h a}^{-1}$ & $\%$ & $\mathbf{m}^{2} \cdot \mathbf{h a}^{-1}$ & $\%$ \\
\hline A.platanoides & 17 & 2.8 & 1.8 & 4.6 \\
A.pseudoplatanus & 210 & 34.8 & 7.6 & 19.1 \\
F. excelsior & 99 & 16.4 & 3.2 & 7.9 \\
F. sylvatica & 135 & 22.4 & 15.3 & 38.4 \\
T. cordata & 54 & 9.0 & 3.2 & 8.1 \\
U. scabra & 18 & 2.9 & 0.7 & 1.6 \\
C.betulus & 47 & 7.8 & 3.2 & 8.1 \\
Q.petrae & 20 & 3.4 & 3.6 & 9.2 \\
A. alba & 3 & 0.5 & 1.2 & 3.0 \\
Total & 603 & 100.0 & 39.8 & 100.0 \\
\hline
\end{tabular}

of all species, the relative frequency means how commonly it occurs - number of occurrences of one species as a percentage of total number of occurrences of all species (Kent, Coker 1992).

Density of natural regeneration according to tree species, height classes (seedlings and saplings) and type of habitat (expanded gap and closed canopy) was tested using Mann-Whitney $U$ test. The relationship between expanded gap size and density of seedlings and saplings

\section{Gap characteristics}

In the area of 2.5 ha, a total number of 25 gaps was recorded: 7 gaps with size up to $300 \mathrm{~m}^{2}, 9$ gaps with size from 301 to $600 \mathrm{~m}^{2}, 6$ gaps with size from 601 to $900 \mathrm{~m}^{2}, 2$ gaps with size from 900 to $2000 \mathrm{~m}^{2}$ a 1 gap with size more than $2000 \mathrm{~m}^{2}$. Canopy gaps and expanded gaps covered $22.8 \%$ and $59.5 \%$ of the research area. The size of expanded gaps ranged from $94 \mathrm{~m}^{2}$ to $3221 \mathrm{~m}^{2}$. The average expanded gap size was $595 \mathrm{~m}^{2}$. The most 
of expanded gaps were concentrated in size category from 200 to $800 \mathrm{~m}^{2}$ (68\%) (Fig. 1).

The size of canopy gaps ranged from $14 \mathrm{~m}^{2}$ to $1694 \mathrm{~m}^{2}$ with the average canopy gap size of $228 \mathrm{~m}^{2}$. The most frequent were canopy gaps with the size up to $300 \mathrm{~m}^{2}$ (64\%), more than $60 \%$ of this category were concentrated in gaps $<100 \mathrm{~m}^{2}$ (Fig. 1).

Although small canopy gaps $\left(<100 \mathrm{~m}^{2}\right)$ made up $40 \%$ of the gaps number, their proportion on the total land area reached only $1.8 \%$. Canopy gaps of the size from 2000 to $3000 \mathrm{~m}^{2}$ covered
$6.8 \%$. The largest recorded expanded gap covered $12.9 \%$ of total land area, whereas the most frequent expanded gaps made up more than $10 \%$ (Fig. 2).

The number of gapmakers per gap ranged from 1 to 37 (Fig. 3). The majority of canopy gaps were created by dying of one (more than 16\%) or 4 gapmakers, respectively. Maximum of 37 gapmakers was recorded for one gap (Fig. 3). The relationship between canopy gap size and number of gapmakers confirmed strong correlation ( $\mathrm{P}<0,001, \mathrm{R}=0.964$ ) (Fig. 4).

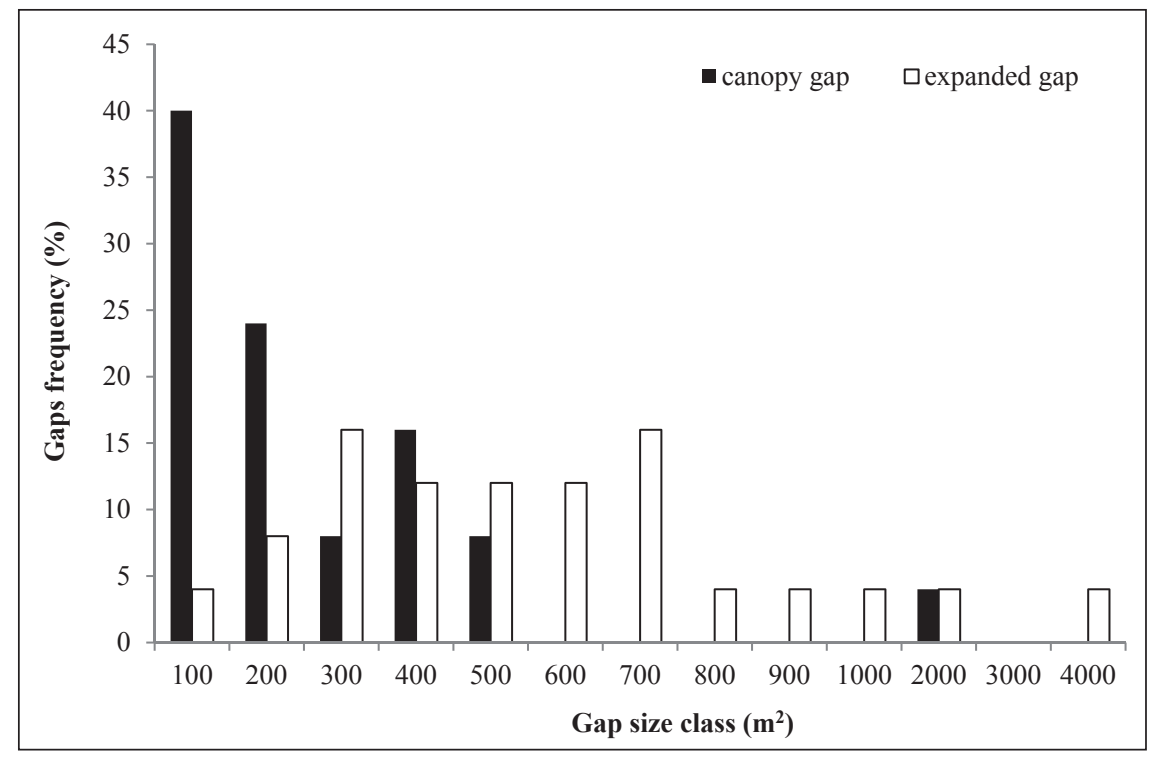

Fig. 1: Frequency of gaps according the gap size classes.

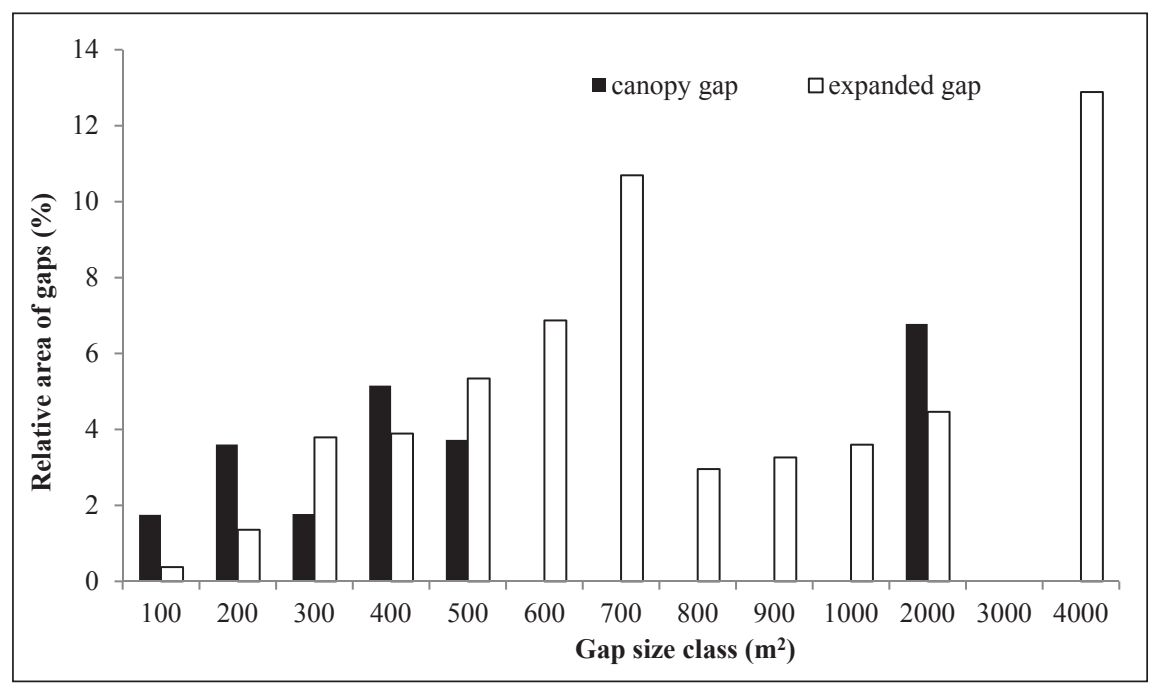

Fig. 2: Proportion of total gaps area according the gap size classes. 


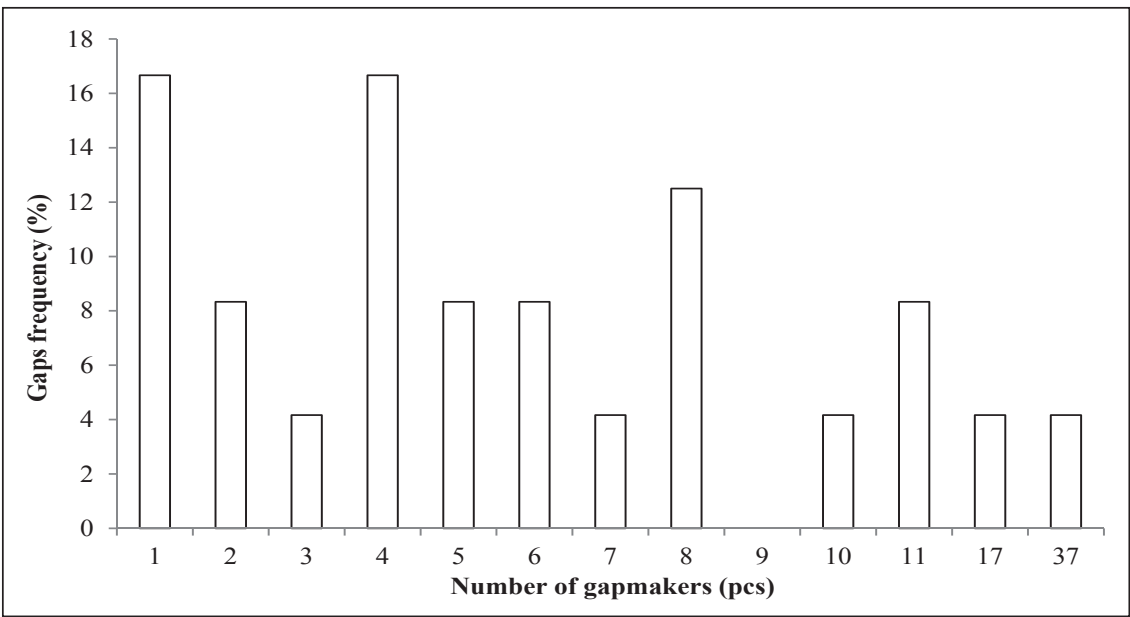

Fig. 3: Gap frequency according to number of gapmakers.

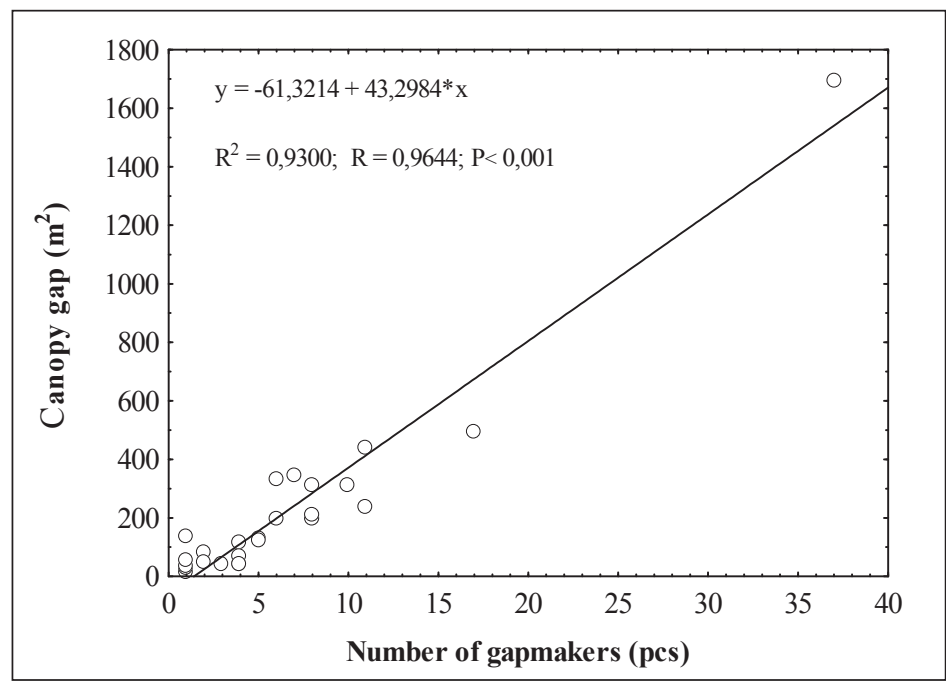

Fig. 4: Relationship between canopy gap size and number of gapmakers.

\section{Tree regeneration}

Eight tree species was identified within natural regeneration in expanded gaps and under canopy (Tab. 2). The total number of seedlings was 54840 pcs.ha $^{-1}$ under canopy and 45987 pcs.ha $^{-1}$ in expanded gaps. The density of all tree species seedlings (except of C. betulus) was higher under canopy than in expanded gaps (Tab. 2).

The most frequent were seedlings of A.pseudoplatanus and A.platanoides which occurred on $80 \%$ and $73 \%$ of the plots under canopy, and $75 \%$ and $68 \%$ of the plots in expanded gaps.
In studied plot we recorded no seedlings of $Q$. petraea.

The density of saplings is smaller in comparison with seedlings, but there was different distribution of tree species between expanded gaps and closed canopy (Tab. 2). Density of saplings was higher in expanded gaps than under closed canopy (except of saplings of $A$. platanoides and T. cordata). Expanded gap regeneration was dominated by saplings of $A$. pseudoplatanus (52.8\%). The individuals of $A$. platanoides and $A$. pseudoplatanus were the most frequent tree species on the plots. 
Tab. 2: Density and frequency of seedlings and saplings under closed canopy (Can) and in expanded gaps (Gap).

\begin{tabular}{|c|c|c|c|c|c|c|c|c|c|c|c|c|}
\hline \multirow{3}{*}{ Tree species } & \multicolumn{6}{|c|}{ Seedlings $(\leq 50 \mathrm{~cm})$} & \multicolumn{6}{|c|}{ Saplings (> $50 \mathrm{~cm})$} \\
\hline & \multicolumn{4}{|c|}{ Density } & \multicolumn{2}{|c|}{ Frequency } & \multicolumn{4}{|c|}{ Density } & \multicolumn{2}{|c|}{ Frequency } \\
\hline & $\begin{array}{c}\text { Can } \\
\left(\text { N.hat }{ }^{-1}\right)\end{array}$ & $\%$ & $\underset{\left(\mathbf{N} \cdot \mathbf{h a}^{-1}\right)}{\text { Gap }}$ & $\%$ & $\begin{array}{c}\text { Can } \\
(\%)\end{array}$ & $\begin{array}{c}\text { Gap } \\
(\%)\end{array}$ & $\begin{array}{c}\text { Can } \\
\left(\mathbf{N} . \mathbf{h a}^{-1}\right)\end{array}$ & $\%$ & $\underset{\left(\mathbf{N} . \mathbf{h a}^{-1}\right)}{\text { Gap }}$ & $\%$ & $\begin{array}{c}\text { Can } \\
(\%)\end{array}$ & $\begin{array}{c}\text { Gap } \\
(\%)\end{array}$ \\
\hline A.platanoides & 15014 & 27.4 & 11363 & 24.7 & 73 & 68 & 4270 & 31.5 & 5732 & 23.9 & 40 & 46 \\
\hline A.pseudoplatanus & 28522 & 52.0 & 27490 & 59.8 & 80 & 75 & 6264 & 46.3 & 12637 & 52.8 & 36 & 58 \\
\hline F.excelsior & 8924 & 16.3 & 5401 & 11.7 & 64 & 48 & 1540 & 11.4 & 3465 & 14.5 & 30 & 40 \\
\hline F.sylvatica & 1225 & 2.2 & 892 & 1.9 & 18 & 17 & 105 & 0.8 & 382 & 1.6 & 3 & 9 \\
\hline T. cordata & 840 & 1.5 & 433 & 0.9 & 9 & 6 & 875 & 6.5 & 561 & 2.3 & 4 & 9 \\
\hline U. scabra & 210 & 0.4 & 153 & 0.3 & 5 & 2 & 455 & 3.4 & 917 & 3.8 & 5 & 13 \\
\hline C.betulus & 105 & 0.2 & 255 & 0.6 & 2 & 4 & 35 & 0.3 & 229 & 1.0 & 2 & 6 \\
\hline Q.petraea & 0 & 0.0 & 0 & 0.0 & 0 & 0 & 0 & 0.0 & 25 & 0.1 & 0 & 1 \\
\hline Total & 54840 & 100.0 & 45987 & 100.0 & 97 & 89 & 13544 & 100.0 & 23949 & 100.0 & 62 & 78 \\
\hline
\end{tabular}
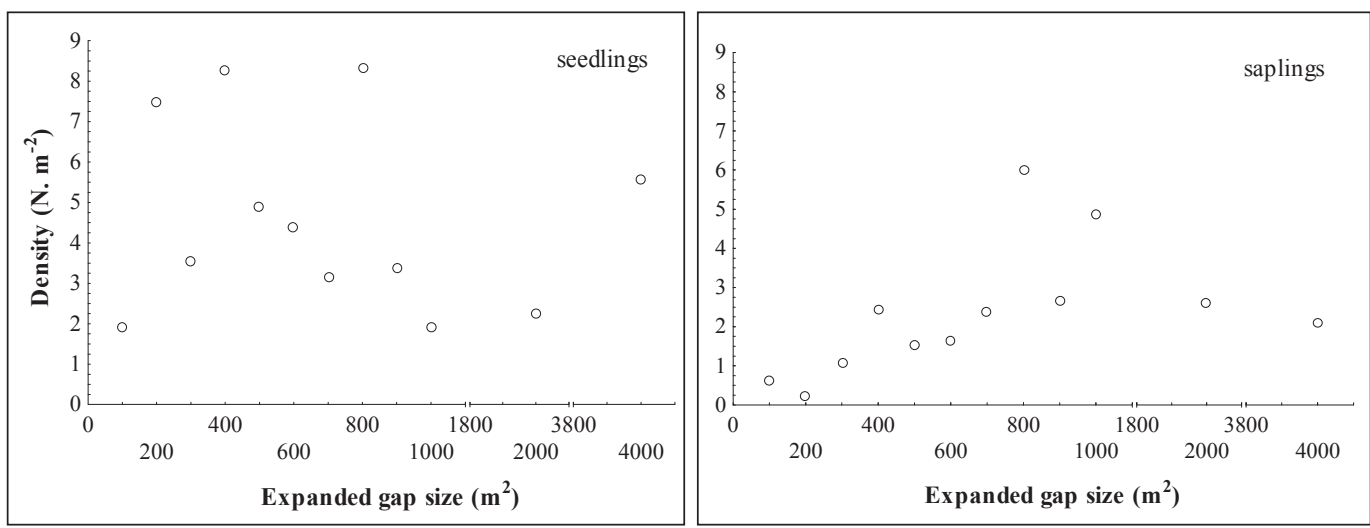

Fig. 5: Density of tree seedlings and saplings in expanded gaps of various sizes.

The difference between density of seedlings and saplings of the most dominant tree species in expanded gaps and under closed canopy was confirmed only for seedlings and saplings of $F$. excelsior (Mann-Whitney $U$ test; $\mathrm{P}<0.05$ ) and for saplings of A. pseudoplatanus (Mann-Whitney $U$ test; $\mathrm{P}<0.05)$.

Total density of natural regeneration and expanded gap were significantly related neither for seedlings (Spearman's $\mathrm{R}=-0.042 ; \mathrm{P}<0.05$ ) nor saplings (Spearman's $\mathrm{R}=0.373 ; \mathrm{P}<0.05$ ). But when the relationship between density and expanded gap size was tested for individual species at different height classes, several of the cases were significant. While the density of saplings of A. pseudoplatanus and A. platanoides increased with expanded gap size (Spearman's $\mathrm{R}=0.718$; $\mathrm{P}<0.05$, resp. 0.601; $\mathrm{P}<0.05$ ), density of $\mathrm{F}$. excelsior showed negative relationship within expanded gap size (Spearman's $\mathrm{R}=-0.594 ; \mathrm{P}<0.05)$. There was no significant relationship between density of seedlings and saplings for other tree species and expanded gap size.

\section{Discussion}

Disturbance regime in multi-species natural forest Sitno is actually characterized by the formation of small-scale gaps. It is generally accepted that in moist temperate European forests, the natural disturbance regime results in small-scale gap dynamics (Emborg et al. 2000, Drößer and Lüpke 2005, Kucbel et al. 2009). 
Canopy-opening events such as treefall produce an increase in tree density because a few large trees are replaced eventually by more small trees. Where tree death results in canopy opening, light at ground level increases. Increased resource availability in treefall gaps results in the release of suppressed seedlings and the germination of seed from soil seed bank (Denslow et al. 1990). The original form of gap partitioning hypothesis explaining how small-scale disturbances enhance diversity in forests predicts that an array of regeneration niches occurs along the gradient from the center of disturbance patch (or canopy gap) to the shaded understory or undisturbed forest (Ricklefs 1977, Denslow 1980). However, some studies show that gap environment is not necessary for successful recruitment (Busing, White 1997, Clinton et al. 1994, Lertzman 1992, Denslow 1995), and results of our study confirm this.

In our study, the density of the seedlings was generally higher under the canopy than in expanded gaps, but the significant differences were confirmed only between seedlings of $F$. excelsior. The opossite situation was discovered in the case of the saplings density. Density of all tree species, except of A. platanoides and T. cordata, tended to be higher in expanded gaps, but only density of A. pseudoplatanus and F. excelsior saplings was shown significantly different. We expected higher densities of young trees in expanded gaps (Gravel et al. 2010) which covered almost $60 \%$ of land area. NNR Sitno is characterized by the volcanic soil with the high level of stoniness resulting in rapid drying-out and water unavailability (lower water-holding capacity). In addition, the combination of higher light irradiance (south orientation of slopes) with shortness of soil water availability can affect higher mortality of tree seedlings. Dense shrub cover can also neutralize recruitment opportunities in canopy gaps (Beckage et al. 2000).

Clinton et al. (1994) showed that seedling density is significantly correlated with percent slope and positively with gap age and with gap size. In our study the gap age was not assessed therefore we could compare the density of recruitments only with gap size. Gap size and the light availability affect not only seedlings establishment but also the survival and growth of saplings. Sapling densities begin to decline as gaps close and establishing saplings compete for space and resources (Denslow 1987). In our study the density of A. platanoides and A. pseudoplatanus sapling increased with gap size. This finding is consistent with results of study from old-growth forest Perucica (Nagel et al. 2010).
This could be caused by higher light demands of these species in their later life stages (Hein et al. 2009). F. excelsior is known to be less shade tolerant than A.pseudoplatanus and F. sylvatica (Ellenberg et al. 1991). However, the abundance of F. excelsior seedlings decreased with expanded gap size. It is well known that F. excelsior is very shade-tolerant in youth (Gia 1927 in Emborg 2007), but in generally the risk of mortality is greater in young trees and their survival is influenced by many factors (Kneeshaw et al. 2006). Regeneration patterns based on the seedling and sapling data clearly reflect the dominance of $A$. pseudoplatanus in these regeneration stages. In spite of low relative abundance of A. platanoides in overstorey, the abundance of young trees was high. The disproportion between density of canopy tree composition of F. sylvatica, T. cordata and Q. petraea and their regeneration could indicate change of tree species composition in the future. The similar trend was observed in mixed-species old-growth forest Hrončekovský Grúň (Saniga et al. 2011).

\section{Acknowledgments}

This study was financially supported by the Slovak Research and Development Agency gran Nr. APVV-0286-10. I would like to thank to Benjamin Jarčuška for his helpful comments and suggestions. 


\section{Literature}

Beaudet, M., Messier, C. 1998: Growth and morphological responses of yellow birch, sugar maple, and beech seedlings growing under a natural light gradient. Canadian Journal of Forest Research, 28: 1007-1015.

Beckage, N., Clark, J.S., Clinton, B.D., Haines, B.L. 2000: A long-term study of tree seedlings recruitment in southern Appalachian forests: the effects of canopy gaps and shrub understories. Canadian Journal of Forest Research, 30: 1617-1931.

Bengtsson, J., Nilsson, S.G., Franc, A., Menozzi, P. 2000: Biodiversity, disturbance, ecosystem function and management of European forests. Forest Ecology and Management, 132: 39-50.

Bobiec, A., Burgt, H., Meijer, K., Zuyderduyn, C., Haga, J., Vlaanderen, B. 2000: Rich deciduous forests in Białowieża as a dynamic mosaic of developmental phases: premises for nature conservation and restoration management. Forest Ecology and Management, 130: 159-175.

Bовіес, A. 2007: The influence of gaps on tree regeneration: a case study of the mixed limehornbeam (Tilio-Carpinetum Tracz. 1962) communities in the Białowieża primeval forest. Polish Journal of Ecology, 55 (3): 441-455.

BRoKaw, N.V.L. 1985: Treefalls, regrowth and community structure in tropical forests. In: Pickett, S.T.A. and White, P.S. (eds.). The ecology of natural disturbances and patch dynamics. Academic Press, Orlando, Florida, USA.

Busing, R.T, White, P.S. 1997: Species diversity and small-scale disturbance in an old-growth temperate forest: a consideration of gap partitioning concepts. Oikos, 78: 562-568.

Clinton, B.D., Boring, L.R., Swank, W.T. 1994: Regeneration patterns in canopy gaps of mixed-oak forests of the southern Appalachians: influences of topographic position and evergreen understory. The American Midland Naturalist Journal, 132: 308-319.

CoAtes, K.D. 2000: Conifer seedling response to northern temperate forest gaps. Forest Ecology and Management, 127: 249-269.

CoATEs, K.D. 2002: Tree recruitment in gaps of various size, clearcut and undisturbed mixed forest of interior British Columbia, Canada. Forest Ecology and Management, 155: 387-398.

Denslow, J.S. 1980: Patterns of plant species diversity during succession under different disturbance regimes. Oecologia, 46: 18-21.
Denslow, J.S. 1987: Tropical rainforest gaps and tree species diversity. Annual Review of Ecology, Evolution and Systematics, 18: 431-451.

Denslow, J.S., Schultz, J., VitouseK, P.M., Strain, B. 1990: Growth responses of tropical shrubs to treefall gap environments. Ecology, 71: 165-179.

Denslow, J.S. 1995: Disturbance and diversity in tropical rain forests: the density effect. Ecological Applications, 5(4): 962-968.

Drösser, L., LÜPKe, B. 2005: Canopy gaps in two virgin beech forest reserves in Slovakia. Journal of Forest Science, 51(10): 446-457.

Einhorn, K.S., Rosenqvist, A., Leverenz, J.W. 2004: Photoinhibition in seedlings of Fraxinus and Fagus under natural light conditions: implications for forest regeneration? Oecologia, 140: 241-251.

Ellenberg, H., Weber, H.E., Dull, R., Wirth, V., Werner, W. \& Paulissen, D. 1991: Zeigerwerte von Pflanzen in Mitteleuropa. Scripta Geobot., 18: 1-248.

Ellenberg, H. 1996: Vegetation Mitteleuropas mit den Alpen. Ulmer Verlag, 1095.

ЕмвоRG, J. 1998: Understorey light conditions and regeneration with respect to the structural dynamics of a near-natural temperate deciduous forest in Denmark. Forest Ecology and Management, 106: 83-95.

Emborg, J., Christensen, M., Heilmann-Clausen, J. 2000: The structural dynamics of Suserup Skov, a near-natural temperate deciduous forest in Denmark. Forest Ecology and Management, 126: 173-189.

ЕмвоRG, J. 2007: Suppression and release during canopy recruitment in Fagus sylvatica and Fraxinus excelsior, dendro-ecological study of natural growth patterns and competition. Ecological Bulletins, 52: 53-67

Gravel, D., Canham, C.D., Beaudet, M., Messier, C. 2010: Shade tolerance, canopy gaps and mechanism of coexistence of forest trees. Oikos, 119: 475-484.

GruBB, P.J. 1977: The maintenance of speciesrichness in plant communities: the importance of the regeneration niche. Biological Reviews.(Camb.), 52: 107-145.

Hein, S., Collet, C., Ammer, C., Le Goff, N., SkovsgaARD, J.P., SAvill, P. 2009: A review of growth and stand dynamics of Acer pseudoplatanus L. in Europe: implications for silviculture. Forestry, 82: 361-385.

Heiri, C., Wolf, A., Rohrer, L., Bugmann, H. 2009: Forty years of natural dynamics in Swiss beech forests: structure, composition, and the influence of former management. Ecological Application, 19 (7): 1920-1934. 
Imai, N., TAKyu, M., Nakamura, Y., Nakamura, T. 2006: Gap formation and regeneration of tropical mangrove forests in Ranong, Thailand. Plant Ecology, 186: 37-46.

JAHN, G. 1991: Temperate deciduous forests of Europe. Ecosyst. World, 7 (13): 377-502.

Kent, M., CoKer, P. 1992: Vegetation description and analysis: a practical approach (Chichester, Wiley)

Kneeshaw, D.D., Kobe, R.K., Coates, D., Messier, C. 2006: Sapling size influences shade tolerance ranking among southern boreal tree species. Journal of Ecology, 94: 471-480.

KoleKTÍv 2004: Plán starostlivosti o SKUEV 0216 Sitno/Holik [Tending plan of Site of Community Importance 0216 Sitno/Holík].

Kucbel, S., Jaloviar, P., Saniga, M., Vencúrik, J., KLimáš, V. 2009: Canopy gaps in an oldgrowth fir-beech forest remnant of Western Carpathians. European Journal of Forest Research, 129: 249-259.

LeI, T.T., Lechowicz, M.J. 1998. Diverse responses of maple saplings to forest light regimes. Annals of Botany, 82: 9-19.

LERTZMAN, K.P. 1992: Patterns of gap-phase replacement in a sub-Alpine, old-growth forest. Ecology, 73: 657-669.

Lirra, J., Sepp, T., KoHv, K. 2011: The ecology of tree regeneration in mature and old forests: combined knowledge for sustainable forest management. Journal of Forest Research, 16: 184-193.

LoeHle, C. 2000: Strategy space and the disturbance spectrum: a life-history model for tree species coexistence. The American Naturalist, 156: 14-33.

Nagel, T.A, Svoboda, M., Rugani, T., Diaci, J. 2010: Gap regeneration and replacement patterns in an old-growth Fagus-Abies forest of Bosnia-Herzegovina. Plant Ecology, 208: 307-318.
Oheimb, G., Westrhal, C., Tempel, H., Härdtle, W., 2005: Structural patterns of a near-natural beech forest (Fagus sylvatica) (Serrahn, North-east Germany). Forest Ecology and Management, 212: 253-263.

OrIANS, G.H. 1982. The influence of tree falls in tropical forests on tree species richness. Trap, 23: 255-279.

RickLEFs, R.E. 1977: Environmental heterogeneity and plant species diversity: a hypothesis. The American Naturalist, 111:376-381.

RuNKLE, J.R. 1981: Gap regeneration in some old-growth forests of the Eastern United States. Ecology, 62(4): 1041-1051.

Runkle, J.R. 1982: Patterns of disturbance in some old-growth mesic forests of Eastern North America. Ecology, 63 (5): 1533-1546.

Saniga, M., Balanda, M., Kucbel, S., Jaloviar, P. 2011: Cyclic changes in tree species composition of mixed-species forest in western Carpathians: role of disturbance and tree regeneration. Polish Journal of Ecology, 59(4): 699-708.

Schnitzer, S.A., Carson, W.P. 200l: Treefall gaps and the maintenance of species diversity in a tropical forest. Ecology, 82 (4):913-919.

ScHÜTz, J-P. 1999: Close-to-nature silviculture: is this concept compatible with species diversity? Forestry, 72 (4): 359-366.

Standovár, T., Kenderes, K. 2003: A review on natural stand dynamics in beechwoods of East Central Europe. Applied Ecology and Environmental Research., 1: 19-46.

ҮАмамото, S. 2000. Forest gap dynamics and tree regeneration. Journal of Forest Research, 5 : 223-229.

White, P.S. 1979: Patterns, process and natural disturbance in vegetation. Botanical Review, 45: 229-299. 
